\title{
THE DEVELOPMENT OF KEFIR MILK STUDENT WORKSHEETS BASED ON FREE INQUIRY ON BIOTECHNOLOGY COURSE
}

\author{
Milla Listiawati*), Nopy Melina \\ Biology Education Programme UIN Sunan Gunung Djati Bandung, Indonesia \\ ${ }^{*}$ E-mail: millalistiawati@gmail.com
}

Doi: https://doi.org/10.31943/mangiferaeduv4i2.48

Received: 10 Desember 2019 Accepted: 29 Januari 2020 Published: 31 Januari 2020

Citasi: Listiawati, M., \& Melina, N. (2020). The Development Of Kefir Milk Student

Worksheets Based On Free Inquiry On Biotechnology Course. Jurnal Mangifera Edu, 4 (2), 116-128

\begin{abstract}
The background of this research is that there are still errors in the practice of making milk kefir in the biotechnology practice guide. Therefore, it is necessary to develop a free inquiry-based kefir worksheet that can be used by prospective teacher students in biotechnology courses. The method used is the research and development method which consists of define, design, and develop stages. Data collection techniques using the method of observation and questionnaires. The subjects of this study were the sixth semester biology education students. The results showed the validity of the questionnaire items had a score of 0.65 with the category of "high" validity. The feasibility test results obtained a value of $88.68 \%$ with the category "feasible". Readability test has a value of 87.65 with the category "very high". The average student performance score of $94 \%$ with the category of "very good", and the value of the use of worksheet scored $92.56 \%$.
\end{abstract}

Keywords: Development Worksheet, Free inquiry, Kefir.

\section{INTRODUCTION}

Learning biology should be able to improve students' thinking skills so that students learn not only to remember facts or material provided but are able to see the various phenomena behind these facts. This can be trained by using learning models such as inquiry (Hadi, Susanti, and Agustini, 2017). Inquiry-based learning refers to the pedagogical strategy that uses the general processes of scientific inquiry as its teaching and learning methodology (Ketpichainarong et al., 2010). Ramadhona and Izzati (2018) state that the inquiry model is a learning model for gaining knowledge by investigating it yourself. Through this model students have the opportunity to discover for themselves what they need during learning. The inquiry model emphasizes the involvement of students both physically and mentally in the learning process. 
Related with the inquiry learning model, the learning can be done by direct investigation by students to prove a fact or theory that can be observed or carried out through practical activities in the laboratory. Of course the implementation of the practicum is not fully controlled by the lecturer but frees students to design and arrange their own practicum activities. This can be helped by the presence of media such as student worksheets.

Worksheets are sheets containing assignments that must be done by students. Worksheets usually contain instructions and steps to complete the task. An assignment contained in a worksheet must have clear basic competencies to be achieved (Majid, 2008). A worksheet should meet didactic requirements, construction terms, technical terms, and characteristics (Supardi et al., 2017). Regarding the worksheets, a preliminary study of the biotechnology course practicum has been conducted through observation and interviews conducted on biology education students in semester VI who have taken biotechnology courses. Based on preliminary studies that have been done, the results show that there are still some errors in the worksheet, such as concept and practice errors in practicing. Surely this is the concern of researchers to make improvements, because it is feared that if this is not intervened, the misconceptions and practices will continue, given the biotechnology practicum is conducted on prospective teacher students.

Therefore there is a need for the development of worksheet that can train students to work scientifically and can develop students' thinking skills so that students have the opportunity to find concepts, build their own knowledge, and play an active role in the learning process (Wahyuningsih, Saputro, and Mulyani, 2014). The design of the inquirybased worksheet had previously been carried out considering the influence that was given from the use of the worksheet on the students' abilities. Based on research conducted by Purnamawati, Ertikanto, and Suyatna (2017) states that the inquiry-based worksheet effectively influences higher-order thinking skills with the acquisition of a value of 0.6 using the effect size test.

The design of this worksheet was carried out in biotechnology courses in the theme of practicum making milk kefir. Milk is one food that contains food substances that are important for the body. The components of these substances include water, carbohydrates, proteins, fats, minerals, and vitamins (Safitri and Swarastuti, 2013). Does not rule out the possibility that the best properties of fresh milk can change, decrease, and even disappear if the processing is not right. This certainly will reduce the nutritional value of milk consumed, so it can be understood that in the current era there is a tendency of interest 
among the community and the milk processing industry to process milk without much reducing the quality of fresh milk as its basic ingredient (Balabanova and Panayotov, 2011).

In addition to decreasing or even losing nutritional content, milk also has another disadvantage that is easily damaged because it is an excellent medium for the growth of beneficial and harmful microbes. Milk processing is done to prevent damage, extend shelf life, and make milk easier to digest. One of the technologies developed at this time is fermented milk. Fermented milk has several benefits and advantages that are good for body health. The fermentation process of milk is able to break down lactose into simpler compounds so that people with lactose intolerance (unable to digest lactose) can still consume it. One example of a product from milk fermentation is kefir (Safitri and Swarastuti, 2013).

According to Hidayat, et al. (2006) explained that kefir is a fermented milk product with a distinctive taste, which is a mixture of sour, alcoholic, and carbonate flavors produced from the fermentation process of bacteria and yeast. In principle, making kefir is the same as making yogurt. With the addition of kefir granules to 5\% and incubated for 812 hours at $22^{\circ} \mathrm{C}$, a kefir beverage product with a $\mathrm{pH}$ of $4-5$, lactic acid content of $0.6-0.8 \%$ and alcohol content varies between $0.5 \%$ - 1\% Farnworth (2005) explains that kefir is a fermented milk product using lactic acid bacteria (LAB) such as Lactobacillus lactis, Lactobacillus delbrueckiisub sp. bulgaricus with yeast and produce lactic acid and ethanol.

Kefir is produced from the metabolic activity of microorganisms found in symbiotic complex structures called kefir grains, namely protein matrix and polysaccharides in the form of yellowish white gel / granules consisting of several types of lactic acid bacteria and acetic acid along with several types of yeast (Dimitreli et al., 2013).

Species of microorganisms in kefir granules include Lactobacillus lactis, Lactobacillus acidophilus, Lactobacillus kefir, Lactobacillus kefir granum, and Lactobacillus parakefir which functions in the formation of lactic acid from lactose. Lactobacillus kefir ranofaciens as mucous forming (kefir grain matrix). Leuconostoc sp. forming diacetyl from citrate. Candida kefir forming ethanol and carbon dioxide from lactose. In addition, kefir seeds are also found in Lactobacillus brevis and yeast (Torulopis holmii and Saccharomyces delbrueckii) (Susanti and Utami, 2014). 
Jurnal Mangifera Edu, Volume 4, Nomor 2, Januari 2020, Halaman 116-128

\section{RESEARCH METHODS}

The method used in this research is a research and development method which is a process for developing a new product or an existing product that can be accounted for (Sukmadinata, 2006). The research and development phase consists of 3 stages, namely the define, design, and develop (3D) stages. Define phase is a preliminary study stage, both theoretically and empirically. The design phase is the stage of designing models and development procedures conceptually-theoretically. The develop phase is conducting an empirical study of initial product development, conducting trials, revisions, and validations (Arifin, Hadisaputro, and Susilaningsih, 2015).

The research subjects consisted of subjects for the validity test, namely expert lecturers as validators and subjects for readability of the questionnaire were students of biology education in semester VI. This research was conducted in June 2019. The procedure of this research is by conducting library studies, analysis of relevant journals, analysis of lesson plan in biotechnology courses, determining learning objectives, designing research procedures, pre-research preparation, making initial design of worksheet, conducting worksheet validation, worksheet revisions, and trials are limited to students. The instruments used in this study were validation test sheets, worksheet readability questionnaire sheets, and student performance assessment sheets.

To analyze the data obtained, the first step taken is to test the validity of items on the validation questionnaire sheet and the worksheet readability questionnaire sheet using Pearson Product-Moment Correlation then the value of the correlation coefficient obtained is interpreted according to the categories listed in Table 1 below.

\section{Table 1. Interpretation amount Correlation Coefficient}

\begin{tabular}{lll}
\hline \multicolumn{1}{c}{ Range } & & Interpretation \\
\hline $0,800 \leq \mathrm{r} \leq 1.00$ & Very high & \\
$0,600 \leq \mathrm{r}<0,800$ & High & \\
$0,400 \leq \mathrm{r}<0.600$ & Enough & \\
$0.200 \leq \mathrm{r}<0,400$ & Low & \\
$0,00 \leq \mathrm{r}<0.200$ & Very low & (Arikunto, 2012)
\end{tabular}

After the validity test is done, the next step is to calculate the average of each aspect or component of the validation questionnaire sheet starting from the aspects of language, presentation, and appearance. The same thing was done with the readability questionnaire sheet. The next step is to determine the eligibility criteria of each validator using the following formula: 


$$
\%=\frac{\sum \mathrm{n}}{\mathrm{N}} \times 100 \%
$$

Information :

$\% \quad$ : Persentase eligibility

$\sum \mathrm{n} \quad$ : A number that selected respondents

$\mathrm{N} \quad$ : Total respondents

(Sudjana, 2009)

The next step is to determine the eligibility criteria of the worksheet in accordance with the predetermined categories, whether the worksheet that have been prepared fall into the category of very feasible, feasible, sufficiently feasible, less feasible, or even very improper. The interpretation of these values can be seen in Table 2 below.

Table 2. Criteria for Eligibility Worksheet

\begin{tabular}{|c|c|}
\hline Percentage $(\%)$ & Qualification \\
\hline $90-100$ & very feasible \\
\hline $80-89$ & Feasible \\
\hline $70-79$ & Sufficiently feasible \\
\hline $60-69$ & Less feasible \\
\hline$<60$ & Very improper \\
\hline
\end{tabular}

(Sudjana, 2009)

The next data analysis is to analyze the student performance sheet in practicing making milk kefir namely by changing the answers on the performance sheet into a score using the Guttman measurement scale, calculating the total score into a value using the following formula:

$$
\mathrm{NP}=\frac{\text { Score }}{\text { Ideal Score }} \times 100 \%
$$

(Sugiyono, 2015)

The next step is to look for an average of each aspect contained in the student performance assessment sheet, starting from doing sterilization, making kefir in accordance with predetermined variables, and harvesting kefir. After knowing the average value in each aspect of the performance appraisal sheet, the value obtained will then be interpreted to determine the category of assessment. The interpretations are in Table 3 below. 
Table 3. Interpretation of Results Student Performance

\begin{tabular}{ll}
\hline \multicolumn{1}{c}{ Score } & \multicolumn{1}{c}{ Criteria } \\
\hline $80-100$ & Very Good \\
$61-80$ & Well \\
$41-60$ & Pretty Good \\
$21-40$ & Not Good \\
\hline
\end{tabular}

(Supardi, 2016)

For worksheet assessments that have been used by students, then use the worksheet assessment rubric that has been made previously.

\section{RESULTS AND DISCUSSION}

The stages of the preparation of inquiry-based milk kefir worksheet are by conducting library studies, analysis of relevant journals, lessons plan analysis of biotechnology courses, determining learning objectives, designing research procedures, pre-research preparation, making initial worksheet designs, conducting worksheet validations, worksheet revisions, and trials are limited to students. The preliminary study was carried out through observation and interviews with students of Biology Education Semester VI regarding worksheets for making kefir in biotechnology courses. The results of the preliminary study were found that there are still concept errors and mistakes in working steps in making kefir.

The next stage is to analyze relevant research journals related to the design of inquiry-based worksheet. The purpose of this activity is to find theories or concepts that are able to support the design of the worksheetI that will be carried out, then an analysis of the lesson plan of biotechnology courses is useful to determine learning outcomes consisting of aspects of attitude, knowledge, and skills.

The learning objectives that are made are adjusted to the learning outcomes that have been analyzed in the lesson plans of biotechnology courses which will then be developed in the research procedures contained in the worksheet which in this procedure must reflect the steps of free inquiry. The design of worksheet that has been made is then tested by three validators who act as validators. The results of the validity tests of worksheet items can be seen in Table 4 below. 
Table 4. Results Validity Worksheet by Validator

\begin{tabular}{|c|c|c|c|}
\hline No. & Statement & rhitung & $\begin{array}{l}\text { Criteria of } \\
\text { Validity }\end{array}$ \\
\hline 1 & $\begin{array}{l}\text { Conformity of the question with Indonesian rules using what } \\
\text { words, why, how, when and where }\end{array}$ & 0,305 & Low \\
\hline 2 & $\begin{array}{l}\text { The ability of worksheets encourages students to think inquiry and } \\
\text { critically }\end{array}$ & 0.672 & High \\
\hline 3 & The multiple interpretations of sentences in student worksheets & 0.952 & Very high \\
\hline 4 & The attractiveness of the cover & 0.977 & Very high \\
\hline 5 & Appropriate type and size of letters used in worksheets & 0.672 & High \\
\hline 6 & $\begin{array}{l}\text { Balance the composition of the layout (Title, author and logo) of } \\
\text { the worksheet }\end{array}$ & 0.672 & High \\
\hline 7 & The discourse in the worksheet is easy to understand & 0.977 & Very high \\
\hline 8 & $\begin{array}{l}\text { Discourse relationships in worksheets have a relationship with } \\
\text { daily life }\end{array}$ & 0,305 & Low \\
\hline 9 & Questions given on worksheets help students explore information & 0.672 & High \\
\hline 10 & $\begin{array}{l}\text { The stages are presented in accordance with the steps of free } \\
\text { inquiry }\end{array}$ & 0,305 & Low \\
\hline 11 & $\begin{array}{l}\text { The tools and materials used for practicing kefir are easily } \\
\text { available }\end{array}$ & 0.672 & High \\
\hline 12 & $\begin{array}{l}\text { Stages in the procedure are arranged systematically and can be } \\
\text { easily understood }\end{array}$ & 0.977 & Very high \\
\hline 13 & $\begin{array}{l}\text { The stages of free inquiry learning in worksheets are arranged in } \\
\text { sequence (problem identification, problem formulation, } \\
\text { hypothesizing, conducting experiments collecting data and } \\
\text { drawing conclusions) }\end{array}$ & 0,305 & Low \\
\hline \multicolumn{2}{|c|}{ Average } & 0.65 & High \\
\hline
\end{tabular}

Based on Table 4, it can be seen that all statements on the validation sheet are included in the valid category with different criteria with an average value of 0.65 which is included in the high validity category. Furthermore, based on the rcount obtained, an average validity calculation for each validation component is calculated. More complete data is presented in the following Table 5.

Table 5. Percentage of Feasibility to Validator

\begin{tabular}{cll}
\hline Validator & \multicolumn{1}{c}{ Average (\%) } & \multicolumn{1}{c}{ Criteria } \\
1 & 98.21 & Very Decent \\
2 & 82.14 & Worthy \\
3 & 85.71 & Worthy \\
Average & 88.69 & Worthy \\
\hline
\end{tabular}

After testing the validity of each statement contained in the validation test sheet, the next step is to determine the eligibility criteria based on the validation results provided by 
each validator. Following are the results of worksheet validation data based on the eligibility criteria in Table 6 below.

Table 6. Results of Worksheet Based Eligibility Criteria Validation

\begin{tabular}{llll}
\hline \multicolumn{1}{c}{ Aspects Validation } & & Average & \multicolumn{1}{c}{ Criteria Validation } \\
\hline Language & .643 & High \\
Display & .774 & High \\
Presentation & 0.602 & High \\
\hline
\end{tabular}

Based on Table 6 the average value of the validation results included in the criteria of feasible and very feasible, thus it can be concluded that worksheet kefir milk based on free inquiry is feasible and ready to be used as a learning resource for students. In addition to the validation test conducted by the validator, the worksheet that was compiled also needed an assessment from students as users. The assessment is done by giving a readability questionnaire to students. In more detail the results of the worksheet readability questionnaire analysis are presented in Table 7 below.

Table 7. Readability Worksheet Test Results to Students

\begin{tabular}{ccl}
\hline Indicator & Score & \multicolumn{1}{c}{ Criteria } \\
\hline 1 & 78.33 & High \\
2 & 86.67 & Very high \\
3 & 91.67 & Very high \\
4 & 95.00 & Very high \\
5 & 93.30 & Very high \\
6 & 86.67 & Very high \\
7 & 90.00 & Very high \\
8 & 83.30 & Very high \\
9 & 85.83 & Very high \\
10 & 85.74 & Very high \\
\hline Average & $\mathbf{8 7 . 6 5}$ & Very high \\
\hline
\end{tabular}

Information :

1. Presentation of discourse in worksheet

6. Intrsuction of designing experiments

2. Step inquiry in worksheet

7. Instruction in experiment

3. Instruction in making the formulation

8. Instruction in presenting the results of of the problem the experiment

4. Instructions for goal setting

5. Instruction in determining hypothesis

9. Instruction in making inferences

10.Instruction in question and discussion

Based on Table 7 shows the results that the questionnaire readability test is mostly included in the very high category but for the indicator of presentation the discourse only 
gets a score of 78.33 with the criteria of "high". This happens because students have not been able to grasp the problems that will be included in the worksheet while in the other nine indicators have "very high" criteria which indicate that kefir milk based on free inquiry worksheet that has previously been designed and validated can be understood by students as worksheet users .

In addition to assessments related to worksheet, student activities in making milk kefir also need to be assessed to what extent the ability of students in making kefir, whether it is in accordance with the standards expected or not. The assessment is carried out using a performance assessment sheet consisting of three aspects, namely assessment in conducting sterilization, assessment in making kefir, and assessment in harvesting kefir. The following is presented in Table 8 about the results of the assessment of student performance in practicing milk making kefir

Table 8 Assessment of Student Performance in the Making Kefir Milk

\begin{tabular}{lccccc}
\hline \multirow{2}{*}{ Rated aspect } & \multicolumn{5}{c}{ Earned Value (\%) } \\
& Ex. 1 & Ex. 2 & Ex. 3 & Ex. 4 & Average \\
\hline $\begin{array}{l}\text { Doing } \\
\text { Sterilization }\end{array}$ & 100 & 83 & 100 & 100 & $95.83 \%$ \\
$\begin{array}{l}\text { Doing Fermented } \\
\text { Milk Kefir }\end{array}$ & 90 & 90 & 100 & 100 & $95.00 \%$ \\
$\begin{array}{l}\text { Doing Harvesting } \\
\text { Kefir }\end{array}$ & 87.5 & 100 & 87.5 & 87.5 & $90.63 \%$ \\
$\begin{array}{l}\text { Average } \\
\text { Criteria }\end{array}$ & $\mathbf{9 2 \%}$ & $\mathbf{9 2 \%}$ & $\mathbf{9 6 \%}$ & $\mathbf{9 6 \%}$ & $94.00 \%$ \\
& Very good & Very good & Very good & Very good & Very good \\
\hline
\end{tabular}

Based on Table 8 it can be seen that the performance of students in making milk kefir is in the criteria of "very good" in the aspects of sterilization, fermentation of kefir, and harvesting kefir. This shows that the performance of students in making milk kefir is in accordance with the expected standards.

In addition to performance appraisals, worksheet used by students is also assessed to determine the extent of students' ability to fill worksheet. The assessment of this worksheet uses collisions that have been made previously. The worksheet assessment results for each component can be seen in Table 9 below. 
Table 9. Assessment Worksheet Used by Students

\begin{tabular}{lc}
\hline \multicolumn{1}{c}{ Spreadsheet Component } & Percent (\%) \\
\hline Formulation of the problem & 96.67 \\
Objective Experiment & 100 \\
Hypothesis & 100 \\
designing experiments & 90.3 \\
experimenting & 100 \\
Presenting Results & 66.67 \\
Summing Trial & 96.41 \\
Discussion & 90.47 \\
\hline \multicolumn{1}{c}{ Average (\%) } & $\mathbf{9 2 . 5 6}$ \\
\hline
\end{tabular}

Based on Table 9, the results obtained indicate that the highest percentage of answers found in the components of the experiment's objectives, hypotheses, and conducting experiments with the same value that is equal to $100 \%$. This can be interpreted that students have been able to make or determine experiments, make hypotheses, and conduct experiments correctly. While the lowest percentage is in the component presenting the results of the experiment. This is because many students present their experimental results in forms and displays that are less effective and communicative so that it makes it difficult for the reader to read the results of the study as a whole.

In this free inquiry-based worksheet, students conduct full inquiry, starting from observation, searching literature, formulating problems, asking questions, designing experiments, compiling and using material tools, collecting and analyzing data, to drawing conclusions. At this stage sometimes students have difficulty because they have to dig and think about background information independently (Anggraeni, 2009). This can be seen in Table 7 that the value of the worksheet readability questionnaire on the first indicator, namely the presentation of discourse in the worksheet has the lowest value of $78.33 \%$. This shows that students have not been able to know the problems that should be excluded.

In addition, based on Table 9, it can be seen that the aspect of presenting the results of the experiment obtained the lowest value of 66.67. This happens because students tend to choose and arrange data or information by designing their own format in which they want to enter more data than what they learn in order to become more confident when the results of the experiment are delivered orally (Anggraeni, 2009). This causes the results of the experiment to be presented in an ineffective and communicative form.

The ability to present the results of an experiment is inversely proportional to the stage of designing an experiment, based on Table 9 aspects of designing an experiment 
gained a value of $90.3 \%$ which at this stage can be dibilinag stages that require caution because it will affect the research results. This is in line with what is explained by (Anggraeni, 2009) that at the stage of designing an experiment students must get a way of solving problems through identifying experiment variables, parameters to be measured, grouping treatments, and planning ways of taking data.

At the hypothesis stage, based on Table 9 a value of $100 \%$ is obtained where formulating this hypothesis is the activity of formulating various possible ideas for the answer to a problem. Testing the hypothesis requires the process of determining the answers that are considered acceptable in accordance with the data or information obtained based on data collection (Sanjaya, 2011).

\section{CONCLUSION}

Based on the research results obtained, it can be concluded is stages of the preparation of free inquiry-based milk kefir worksheet in biology courses include literature studies, analysis of relevant journals, lessons plan analysis of biotechnology courses, determining learning objectives, designing research procedures, designing worksheet, and conducting worksheet validation tests to produce products in the form of milk kefir free inquiry-based worksheet.

The results of the feasibility test on the milk kefir free inquiry-based worksheet in biology courses have met the criteria of high validity with an average rcount of 0.65 and were declared eligible based on the results of calculating the eligibility criteria of the $1 \mathrm{st}$ validator of $98.21 \%$ ( very feasible), the second validator is $82.14 \%$ (feasible), and the third validator is $85.71 \%$ (feasible) so it is ready to be used by students.

Student performance in practicing milk making kefir obtained a score of $94.00 \%$ with very good criteria. The results of the use of milk kefir inquiry-based worksheet from eight components worksheet obtained a value of $92.56 \%$.

\section{REFERENCES}

Anggraeni, S. (2009). Kemampuan Melakukan Inkuiri Bebas dan Dampaknya terhadap Sikap Ilmiah dari Calon Guru Biologi. Prosiding Seminar Nasional Penelitian, Pendidikan, dan Penerapan MIPA Fakultas MIPA, Universitas Negeri Yogyakarta, 16 Mei 2009. Hlm 332-339.

Arifin, U. M., Hadisaputro, S., dan Susilaningsih, E. (2015). Pengembangan Lembar Kerja Praktikum Siswa Terintegrasi Guided Inquiry untuk Keterampilan Proses Sains. Chemistry in Education, 4(1), 54-60. 
Arikunto, S. (2012). Prosedur Penelitian : Suatu Pendekatan Praktik. Jakarta : Rineka Cipta.

Balabanova, T dan Panayotov, P. (2011). Obtaining Functional Fermented Beverages by Using the Kefir Grains. Procedia Food Science, 1(2011), 1653-1659. doi: 10.1016/j.profoo.2011.09.244.

Dimitreli,G., dkk. (2013). Rehological Properties of Kefir as Affected by Heat Treatment and Whey Protein Addition. Journal of Texture Studies, 44(2013), 418-423. doi : 10.1111/jtxs.12030

Farnworth, E.R. (2005). Kefir-A Complex Probiotic Food Research and Development Centre. Agriculture and Agrifood, Canada, ST. Hyacin the Queback, Canada.

Hadi, S. A., Susantini, E., Agustini, R. (2017). Bahan Ajar Mahasiswa Berorientasi pada Inkuiri Bebas Termodifikasi untuk Melatihkan Keterampilan Berpikir Kritis. Jurnal Studi dan Ilmu Pendidikan Islam, 1(1), 1-8.

Hidayat, N., dkk. (2006). Mikrobiologi Industri. Yogyakarta: Andi.

Ketpichainarong, W., Panijpan, B., \& Ruenwongsa, P. (2010). Enhanced learning of biotechnology students by an inquiry-based cellulase laboratory. International Journal of Environmental and Science Education, 5(2), 169-187.

Majid, A. (2008). Perencanaan Pembelajaran. Bandung : PT. Remaja Rosda Karya.

Purnamawati, D., Ertikanto, C., dan Suyatna, A. (2017). Keefektifan Lembar Kerja Siswa Berbasis Inkuiri untuk Menumbuhkan Keterampilan Berpikir Tingkat Tinggi. Jurnal Ilmiah Pendidikan Fisika Al-Biruni, 6(2), 209-219. doi : 10.24042.jipfalbiruni.v6i2.2070.

Ramadhona, R., dan Izzati, N. (2018). Pengembangan Lembar Kerja Mahasiswa Berbasis Inkuiri Mata Kuliah Matematika Umum untuk Mahasiswa Pendidikan Kimia. Jurnal Kiprah, 6(2), 21-24.

Safitri, M. F., dan Swarastuti, A. (2013). Kualitas Kefir Berdasarkan Konsentrasi Kefir Grain. Jurnal Aplikasi Teknologi Pangan, 2(2), 87-92.

Sanjaya, W. (2011). Strategi Pembelajaran Berorientasi Standar Proses Pendidikan. Jakarta : Kencana Prenada Media.

Sudjana. (2009). Dasar-Dasar Proses Belajar Mengajar. Bandung : Penerbit Sinar Baru Algesindo.

Sugiyono. (2015). Metode Penelitian Kuantitatif, Kualitatif, $R \& D$. Bandung: Alfabeta.

Sukmadinata. (2006). Metode Penelitian Pendidikan. Bandung : Remaja Rosda Karya.

Supardi. (2016). Penilaian Autentik Pembelajaran Afektif, Kognitif, dan Psikomotor (Konsep dan Aplikasi). Jakarta : Raja Grafindo Persada. 
Supardi, S., Ertikanto, C., \& Manurung, P. (2017). Student Worksheet Static Fluid Material Based on Scientific Approach Using Giuded Inquiry Model. International Journal of Science and Applied Science: Conference Series, 2(1), 368-380.

Susanti dan Utami, S. (2014). Pengaruh Lama Fermentasi terhadap Kandungan Protein Susu Kefir sebagai Bahan Penyusun Petunjuk Praktikum Mata Kuliah Biokimia. Florea, 1(1), 41-46.

Wahyuningsih, F., Saputro, S., dan Mulyani, S. (2014). Pengembangan LKS Berbasis Inkuiri Terbimbing pada Materi Pokok Hidrolisis Garam untuk SMA/MA. Jurnal Paedagogia, 17(1), 94-103. 